\title{
Exploration and Characterization of Cyanobacteria from Different Ecological Niches of India for Phycobilins Production
}

\author{
Samadhan Yuvraj Bagul*, Sneha Tripathi, Hillol Chakdar, N. Karthikeyan, \\ K. Pandiyan, Arjun Singh and M. Kumar
}

ICAR-National Bureau of Agriculturally Important Microorganisms, Mau, U.P. 275103, India

*Corresponding author

\begin{abstract}
A B S T R A C T
Keywords

Cyanobacteria,

Phycobilin,

Carotenoid,

Chlorophyll,

Heterocystous,

Non-heterocystous

Article Info

Accepted:

20 November 2018

Available Online:

10 December 2018

Cyanobacteria are photosynthetic microorganisms capable of producing high value pigments like phycoerythrin, phycocyanin, allophycocyanin, chlorophyll and carotenoids. These high value pigments have immense commercial value as they have applications in food, pharmaceutical and cosmetic industries. In the present study, using soil and water samples collected from different ecological niches of India, 10 isolates of heterocystous and 09 isolates of non- heterocystous cyanobacteria were obtained. Morphological identification revealed that the isolates belonged to Nostoc, Anabaena, Phormidium, Lyngbya, Westiellopsis, Aphanotheca, Oscillatoria, Tolypothrix and Chroococcus. When these isolates were screened for phycoerythrin, Nostoc sp. BG1 was recorded with highest $(870 \mu \mathrm{g} / \mathrm{mL})$ production. Determination of phycocyanin revealed Nostoc sp. RD1 to be the highest $(450 \mu \mathrm{g} / \mathrm{mL})$ producer. Westiellopsis sp. BG2 was found to produce maximum $(530 \mu \mathrm{g} / \mathrm{mL})$ of Allophycocyanin. Likewise, Phormidium sp. SB6 was recorded as highest Chlorophyll a $(270 \mu \mathrm{g} / \mathrm{mL})$ producer. In case of carotenoids, Lyngbya sp. SB2 showed maximum $(13 \mu \mathrm{g} / \mathrm{mL})$ production. These isolates can be potential candidates for high value pigment production and could be exploited for commercial use in future.
\end{abstract}

\section{Introduction}

Cyanobacteria are photosynthetic, gram negative microorganisms capable to fix nitrogen and produce high value products like phycobilins (PBP), carotenoides and polyunsaturated fatty acids which have immense application in pharmaceutical, food, cosmetic industry (Begum et al., 2016). These photosynthetic organisms are present in diverse ecological niches ranging from extreme hot, cold and hypersaline environment, aquatic to terrestrial, ultra- oligotrophic and hypereutrophic (Bhatnagar and Bhatnagar, 2005). Cyanobacteria are morphologically diverse phyla of prokaryotes showing 323 genera with more than 2000 species (Sharma et al., 2014; Nabout et al., 201; Guiry, 2012). Large amount of diversity exists in cyanobacteria comprising unicellular to filaments, branched to unbranched and colonial to complex cell structure. High growth rate and wider adaptability makes cyanobacteria excellent candidate for mass production of various industrially important compounds (Encarnacao et al., 2015). In this 
fast growing era, synthetic chemicals have been utilized heavily as colorants in food and cosmetic industries which are carcinogenic and have detrimental effect on health (Amchova et al., 2015). Cyanobacteria is good source of natural colorant known as PBP free from toxic effects and have numerous health benefits. Cyanobacterial pigments are gaining an importance as natural colorant over synthetic colorant in food and biotechnological industries (Dasgupta, 2015). Apart from natural colorants, PBP could be used as fluorescent label in immunoassays and in microscopy for diagnostic and biomedical research for cancer daignostic, due to their spectroscopic and fluorescence properties (CQVB, 1988; Hill, 1988; Soni et al., 2006). Phycocyanin of Spirulina platensis as a natural colorant has been used in products such as dairy products and jellies (Santiago-Santos et al., 2004), fermented milk products, ice creams, deserts (Sekar and Chandra-Mohan, 2008).

Many multinational companies have been using colorants made from red algae and cyanobacteria among them Fujifilm corporation with Astalift whitening essence a astaxanthin based product for antiaging, similarly Japanese firm Kose used astaxanthin based product AstaBlanc as anti-wrinkle, Cphycocyanin by Prozyme (PhycoPro ${ }^{\mathrm{TM}}$ ), Cphycocyanin by Cyanotech (Phycolink ${ }^{\mathrm{TM}}$ ) and other companies involved are Europa bioproducts Ltd, Sigma Aldrich, Fishcer scientific etc. (Chakdar and Pabbi 2017, Chakdar et al., 2012).

Dianipon Ink Corporation from Japan commercially marketing Linablue, a phycocyanin product as a natural colorant from Spirulina platensis (Chakdar et al., 2012). Antioxidant activity of PBP extracted from Lyngbya sp. A09DM have been reported (Sonani et al., 2014). PBP are water soluble light harvesting pigment-protein complexes present in cyanobacteria, red algae and cryptophytes (Apt et al., 1995; Glazer and Apell, 1977). Antiallergic and antiinflammatory activity of cyanobacteria has also been reported by many researchers (Hayashi et al., 1996; Egorova et al., 2005). Phycobilins have been grouped into blue phycocyanin $\left(\lambda_{\max } \sim 610-625 \mathrm{~nm}\right.$, pink phycoerythrin $\left(\lambda_{\max } \sim 490-570 \mathrm{~nm}\right)$ and allophycocyanin $\left(\lambda_{\max } \sim 650-660 \mathrm{~nm}\right.$ ) (Kuddus et al., 2013; Singh et al., 2015; Manirafash et al., 2016). Phycocyanin producing strain Arthrospira platensis (Lee et al., 2016), Anabaena (Chakdar et al., 2014), Nostoc (Lee et al., 2017) are currently exploited for commercial production. Commercial value of analytical grade phycocyanin purity more than 4.0 can be estimated as USD 15 per $\mathrm{mg}$ (Cisneros and Rito-Palomeares, 2004). Despite the diversity among cyanobacteria very few strains have been reported as potential pigment producer. Pigment production from cyanobacteria varies from species to species and mostly depends on environmental factors (Chaneva et al., 2007; Sarda et al., 1999). Present study deals with isolation of cyanobacteria from diverse ecological habitat and their potential for pigments production.

\section{Materials and Methods}

\section{Sample collection}

Soil and water samples were collected from different ecological niches of India including the districts of Odisha (Kendrapada, Puri, Ganjam), Jammu and Kashmir (Panggong lake, Nubra valley), Uttarakhand (Valley of Flower), Uttar Pradesh (Ballia) and Assam (Guhawati). Details of the samples are presented in table 1. Water and soil samples were stored in autoclaved plastic bottles and brought to the laboratory for isolation and purification of the cyanobacteria. $\mathrm{pH}$ and $\mathrm{EC}$ of the samples were also measured with standard method. 


\section{Isolation, identification and purification}

$10 \mathrm{~g}$ of soil from each sample was taken and processed for serial dilution. $1 \mathrm{ml}$ of aliquots was spread on BG 11 agar plates with nitrogen source for non heterocystous strain and without nitrogen source for heterocystous strain. Waters samples were processed as such in the BG 11 broth. The flasks were incubated at $27 \pm 1{ }^{\circ} \mathrm{C}, 50-55 \mu \mathrm{mol}$ photons $\mathrm{m}^{-2} \mathrm{~s}^{-1}$ light intensity and 16:8 light and dark cycle and axenic cultures were obtained by the procedure given by Stanier et al., (1971). The pure cultures were maintained in BG11 broth in culture room for further experiment.

\section{Morphological identification through microscopy}

Microscopic observations of cyanobacterial isolates were taken by bright field with $\times 40$ (Olympus BX41, Japan) microscope and identification was done by taxonomic keys provided by Desikachary (1959). Among the morphological characteristics filament color, heterocyst formation and position on filament, trchichome end etc. were documented.

\section{Extraction and estimation of PBP}

Phycobililn pigments (PC, PE and APC) were extracted according to the method given by Bennet and Bogorad (1973). $10 \mathrm{ml}$ of algal culture was centrifuged at $7000 \mathrm{rpm}$ for 10 minutes. The pellets were suspended in $5 \mathrm{ml}$ of $0.1 \mathrm{M}$ phosphate buffer. The pigments were extracted by repeated freezing $\left(-20{ }^{\circ} \mathrm{C}\right)$ and thawing at room temperature. The supernatants were collected and absorbance was measured at $562 \mathrm{~nm}, 561 \mathrm{~nm}$ and $652 \mathrm{~nm}$ for phycocyanin, allophycocyanin and phycoerythrin respectively using UV-visible spectrophotometer (Shimadzu 1700). Phycocayninan, phycoerythrin and allophycicyanin was estimated by following equations and expressed in $\mu \mathrm{g} / \mathrm{mL}$.
$\mathrm{PC}=\left[A_{615^{-}}\left(0.474 \times A_{652}\right)\right] / 5.34$

$\mathrm{APC}=\left[A_{652}-\left(0.208 \times A_{615}\right)\right] / 5.09$

$\mathrm{PE}=\left[A_{562}-(2.41 \times \mathrm{PC})-(0.849 \times \mathrm{APC})\right] / 9.62$

\section{Estimation of total carotenoides}

Total carotenoids were determined by the method given by Jensen (1978). $10 \mathrm{ml}$ of homogeneized algal suspension was centrifuged at $6500 \mathrm{rpm}$ for 10 minutes. Supernatants were discarded and $3 \mathrm{ml} \mathrm{85 \%}$ acetone was added in to the pellets. The contents then subjected to repeated freezing and thawing until the pellets become colorless. Final volume of the content was made up to $10 \mathrm{ml}$ with $85 \%$ acetone and absorbance was measured at $450 \mathrm{~nm}$ using $85 \%$ acetone as blank. Carotenoid concentration was estimated as per the equation given below

Carotenoids $(\mu \mathrm{g} / \mathrm{mL})=\left[\mathrm{A}_{461}-\left(0.046 \times \mathrm{A}_{664}\right)\right]$ $\times 4$

\section{Estimation of chlorophyll}

Chlorophyll $\mathrm{a}$ and $\mathrm{b}$ was estimated by the method described by Mckinney (1941). $10 \mathrm{ml}$ of algal culture was centrifuged at $7000 \mathrm{rpm}$ for 10 minutes. The pellets were suspended in $10 \mathrm{ml}$ of $90 \%$ methanol in test tubes and covered with aluminium foil and placed in water bath at $60^{\circ} \mathrm{C}$ for 30 minute. The absorbance of the supernatant was measured at 650 and $665 \mathrm{~nm}$.

Chlorophyll a $=2.55 \times 10^{-2} A_{650}+0.4 \times 10^{-2}$ $A_{665}$

\section{Results and Discussion}

Soil and water samples collected from different ecological niches of India showed diversity among cyanobacterial genera. Table 2 presents different cyanobacteria isolated from respective ecological niches. 50\% of the cyanobacterial isolates were heterocystous 
while the rest were non-heterocystous. Among heterocystous cyanobacteria, Anabaena sp., Nostoc sp., Westielopsis sp., Tolypothrix sp., Cylindrospermum sp. were isolated (Plate 1). While non heterocystous cyanobacteria included Lyngbya sp., Phormidium sp., Oscillatoria sp., Aphanothece sp., and Chroococcus sp. (Plate 2). Morphological characteristics of the isolates are presented in Table 2. All the pure cultures were accessioned and submitted to National Agriculturally Important Microbial Culture Collection (NAIMCC), Mau, Uttar Pradesh, India (Table 3). These isolates were investigated for pigment production. Among all the isolates Nostoc sp. BG1 was recorded with highest $(870 \mu \mathrm{g} / \mathrm{mL})$ phycoerythrin while lowest $(21 \mu \mathrm{g} / \mathrm{mL})$ was recorded in Chroococcus sp. SB 4.

Determination of phycocyanin revealed Nostoc sp. RD1 to be the highest $(450 \mu \mathrm{g} / \mathrm{mL})$ producer however, lowest was recorded (10 $\mu \mathrm{g} / \mathrm{mL})$ in Chroococcus sp. HC1. Westeillopsis sp. BG2 was found to produce maximum $(530 \mu \mathrm{g} / \mathrm{mL})$ of Allophycocyanin. Tiwari et al., (2015) also obtained similar kind of results and found Phormidium arthurensis BTA042 and Nostoc muscorum BTA 087 were rich in phycoerythrin. Simeunovic et al., (2012) studied phycobilin pigments of filamentous cyanobacteria and found Anabaena strain $\mathrm{C} 2$ could produce $22.62 \mu \mathrm{g} / \mathrm{ml}$ of phycocyanin and Anabaena LC1B producing $24.87 \mu \mathrm{g} / \mathrm{ml}$ of phycoerythrin. PC concentration of Synechococcus $\mathrm{sp}$. and Nostoc spumigena was reported as $0.79 \mu \mathrm{g} / \mathrm{cm}^{-3}$ and $20.22 \mu \mathrm{g} / \mathrm{cm}^{-3}$ respectively by Sasim et al., (2014).

Horvath et al., (2013) reported higher extraction efficiency of phycocyanin with freezing and thawing along with sonication in Cylindrospermopsis raciborskii. Khatoon et al., (2018) reported highest phycobilin yield of $237 \mathrm{mg} / \mathrm{g}$ in Pseudoanabaena mucicola when cultivated in waste water and white light. Hemlata and Fatma (2009) extracted phycobilin from Anabaena NCCU-9 and reported $91.54 \mathrm{mg} / \mathrm{g}$ dry weight.

Khazi et al., (2018) investigated cyanobacteria for phycobilin production under different nitrogen sources and found Phormidium sp. and Pseudoscillatoria sp could yield phycobilin pigments of $19.38 \%$ and $19.99 \%$ of dry weight in presence of ammonium chloride, however, sodium nitrate was found best for Arthrospira platensis which could produce $22.27 \%$ of dry weight. Among cyanobacterial pigments allophycocyanin is naturally found in lower amount approximately $10 \%$ of the total cell biomass than phycocyanin and phycoerythrin.

Phormidium sp. SB6 was recorded as highest Chlorophyll a $(270 \mu \mathrm{g} / \mathrm{mL})$ producer and lowest was recorded in Tolypothrix sp. RC1 (23 $\mu \mathrm{g} / \mathrm{mL}$ ). In case of carotenoids Phormidium sp. SB6 showed maximum (13.3 $\mu \mathrm{g} / \mathrm{mL}$ ) production (Fig. 1). Tiwari et al., (2015) recorded carotenoid yield of 80.3 $\mu \mathrm{g} / \mathrm{mL}$ in Nostoc muscorum BTA087 isolated from Manipur region of India.

Shukla and Kashyap (2003) investigated Antartic and tropical cyanobacterial strains for carotenoides production and reported that Nostoc sp. could produce $36.4 \mu \mathrm{g} / \mathrm{mg}$ dry weight of carotenoid and Phormidium sp. resulted in $22.6 \mu \mathrm{g} / \mathrm{mg}$ dry weight. Cyanobacteria including Phormidium laminosum (Fresendo et al., 1991), Synechococcus sp. PCC 7942 (Linden et al., 1990) and Nostoc commune (Olie and Potts 1986) have been reported to be rich source of carotenoids. Various environmental factors are also responsible for cyanobacterial pigment production and composition. Amount of phycobilins production depends on light, temperature, $\mathrm{pH}$ and nutrient source (Hemlata and Fatma 2009) (Fig. 2 and 3). 
Table.1 Details of geographical locations of samples collection sites in India with physicochemical characteristics of soil

\begin{tabular}{|l|l|l|l|l|}
\hline Locations & Habitat & $\begin{array}{l}\text { Latitude and Longitude } \\
\text { (In degrees) }\end{array}$ & $\begin{array}{l}\mathrm{EC} \\
(\mu \mathrm{S} / \mathrm{cm})\end{array}$ & $\mathrm{pH}$ \\
\hline $\begin{array}{l}\text { Panggong lake, Leh (Jammu and } \\
\text { Kashmir) }\end{array}$ & Water & $33.75 \mathrm{~N}, 78.66 \mathrm{E}$ & 216 & 7.8 \\
\hline Phephna, Ballia (Uttar Pradesh) & Arsenic contaminated soil & $25.77 \mathrm{~N} ; 84.03 \mathrm{E}$ & 107.8 & 6.7 \\
\hline Ekauna, Ballia (Uttar pradesh) & Arsenic contaminated Soil & $25.71 \mathrm{~N}, 84.27 \mathrm{E}$ & 214 & 6.9 \\
\hline Chilka lake (Odisha) & Water & $19.84 \mathrm{~N}, 85.47 \mathrm{E}$ & 840 & 6.6 \\
\hline Bhitarkanika (Odisha) & Water & $20.71 \mathrm{~N}, 86.82 \mathrm{E}$ & 251 & 7.7 \\
\hline Brahamagiri (Odisha) & Soil & $19.78 \mathrm{~N}, 85.61 \mathrm{E}$ & 270 & 7.9 \\
\hline Atri hot spring (Odisha) & Hot water & $20.15 \mathrm{~N}, 85.30 \mathrm{E}$ & 233 & 7.4 \\
\hline Puri (Odisha) & Sand & $85.83 \mathrm{~N}, 19.81 \mathrm{E}$ & 1200 & 8.0 \\
\hline Guwahati (Assam) & Soil & $26.14 \mathrm{~N}, 91.73 \mathrm{E}$ & 210 & 5.5 \\
\hline Valley of Flower (Uttarakhand) & Soil & $30.72 \mathrm{~N}$ and 79.60 E & 57.9 & 9.5 \\
\hline
\end{tabular}

Table.2 Morphological/taxonomical characteristics of cyanobacteria isolated from different ecological niches of India

\begin{tabular}{|c|c|c|c|c|}
\hline \multirow[t]{2}{*}{ Cyanobacterial strain } & \multirow[t]{2}{*}{ Habit } & \multicolumn{3}{|l|}{ Taxonomical description } \\
\hline & & Heterocyst & $\begin{array}{l}\text { Cell/filament } \\
\text { color }\end{array}$ & Trichome ends \\
\hline Nostoc sp. HC2 & $\begin{array}{l}\text { Valley of Flower, } \\
\text { Uttarakhand }\end{array}$ & Spherical, & $\begin{array}{l}\text { Olive green, } \\
\text { entatangled }\end{array}$ & Spherical \\
\hline Nostoc sp. BG1 & $\begin{array}{l}\text { Brahamagiri. } \\
\text { Odisha }\end{array}$ & Oblong & Blue green & Elongated \\
\hline Anabaena sp. BG1 & $\begin{array}{l}\text { Brahamagiri, } \\
\text { Odisha }\end{array}$ & $\begin{array}{l}\text { Oval, } \\
\text { terminal, intercalary }\end{array}$ & Dark blue green & Elongated \\
\hline Lyngbya sp. SB2 & Atri, Odisha & Absent & Blue green & Flat \\
\hline Anabaena sp. SB1 & Bhitarkanika, Odisha & $\begin{array}{l}\text { Spherical, } \\
\text { terminal, intercalary }\end{array}$ & Yellowish green & Round \\
\hline Oscillatoria sp. SK2 & Leh, Jammu and Kashmir & Absent & Olive green & Flat, conical \\
\hline Westeillopsis sp. BG2 & $\begin{array}{l}\text { Brahamagiri, } \\
\text { Odisha }\end{array}$ & $\begin{array}{l}\text { Oblong } \\
\text { intercalary }\end{array}$ & $\begin{array}{l}\text { Dark green, } \\
\text { Branched }\end{array}$ & Round, conical \\
\hline Chroococus sp. HC1 & Valley of flower, Uttarakh: & Absent & Group of 4 cells & - \\
\hline Westeillopsis sp. SB10 & Puri, Odisha & $\begin{array}{l}\text { Spherical, } \\
\text { Intercalary }\end{array}$ & $\begin{array}{l}\text { Blue green, } \\
\text { branched }\end{array}$ & Round \\
\hline Chroococcus sp. SB4 & Atri, Odisha & Absent & $\begin{array}{l}\text { Group of 8-16 } \\
\text { cells }\end{array}$ & - \\
\hline Aphanothece sp. SB3 & Guhawati, Assam & Absent & Barrel shape & - \\
\hline Nostoc sp. SK1 & Leh, Jammu and Kashmir & Spherical, terminal, intercalary & Dark green & Round \\
\hline Tolypothrix sp. RC1 & Ballia, Uttar Pradesh & Square, Terminal, intercalary & Yellowish green & Round \\
\hline Nostoc sp. RD1 & Ballia Uttar Pradesh & Barrel, intercalary & Dark green & Oval \\
\hline Lyngbya sp. Rh1 & Ballia Uttar Pradesh & Absent & Blue green & Conical \\
\hline Phormidium sp. RC2 & Ballia Uttar Pradesh & Absent & Dark green & - \\
\hline Phormidium sp. SB9 & Chilka, Odisha & Absent & Dark green & - \\
\hline Phormidium sp. SB6 & $\begin{array}{l}\text { Leh, Jammu and } \\
\text { Kashmir }\end{array}$ & Absent & Dark green & - \\
\hline
\end{tabular}


Table.3 Cyanobacterial accessions submitted to NAIMCC

\begin{tabular}{|l|l|l|}
\hline Sr. No. & Strain name & NAIMCC accession No. \\
\hline $\mathbf{1}$ & Nostoc sp. HC2 & NAIMCC-C-C-00239 \\
\hline $\mathbf{2}$ & Nostoc sp. BG1 & - \\
\hline $\mathbf{3}$ & Anabaena sp. BG1 & NAIMCC-C-C-00236 \\
\hline $\mathbf{4}$ & Lyngbya sp. SB2 & NAIMCC-C-C-00241 \\
\hline $\mathbf{5}$ & Anabaena sp. SB1 & NAIMCC-C-C-00234 \\
\hline $\mathbf{6}$ & Oscillatoria sp. SK2 & NAIMCC-C-C-00244 \\
\hline $\mathbf{7}$ & Westeillopsis sp. BG2 & NAIMCC-C-C-00237 \\
\hline $\mathbf{8}$ & Chroococus sp. HC1 & NAIMCC-C-C-00238 \\
\hline $\mathbf{9}$ & Westeillopsis sp. SB10 & NAIMCC-C-C-00235 \\
\hline $\mathbf{1 0}$ & Chroococcus sp. SB4 & NAIMCC-C-C-00242 \\
\hline $\mathbf{1 1}$ & Aphanothece sp. SB3 & NAIMCC-C-C-00243 \\
\hline $\mathbf{1 2}$ & Nostoc sp. SK1 & - \\
\hline $\mathbf{1 3}$ & Tolypothrix sp. RC1 & NAIMCC-C-C-00229 \\
\hline $\mathbf{1 4}$ & Nostoc sp. RD1 & NAIMCC-C-C-00231 \\
\hline $\mathbf{1 5}$ & Lyngbya sp. Rh1 & NAIMCC-C-C-00232 \\
\hline $\mathbf{1 6}$ & Phormidium sp. RC2 & NAIMCC-C-C-00230 \\
\hline $\mathbf{1 7}$ & Phormidium sp. SB9 & NAIMCC-C-C-00233 \\
\hline $\mathbf{1 8}$ & Phormidium sp. SB6 & NAIMCC-C-C-00240 \\
\hline
\end{tabular}

Fig.1 Estimation of total phycobilin from cyanobacteria isolated from different ecological niches of India

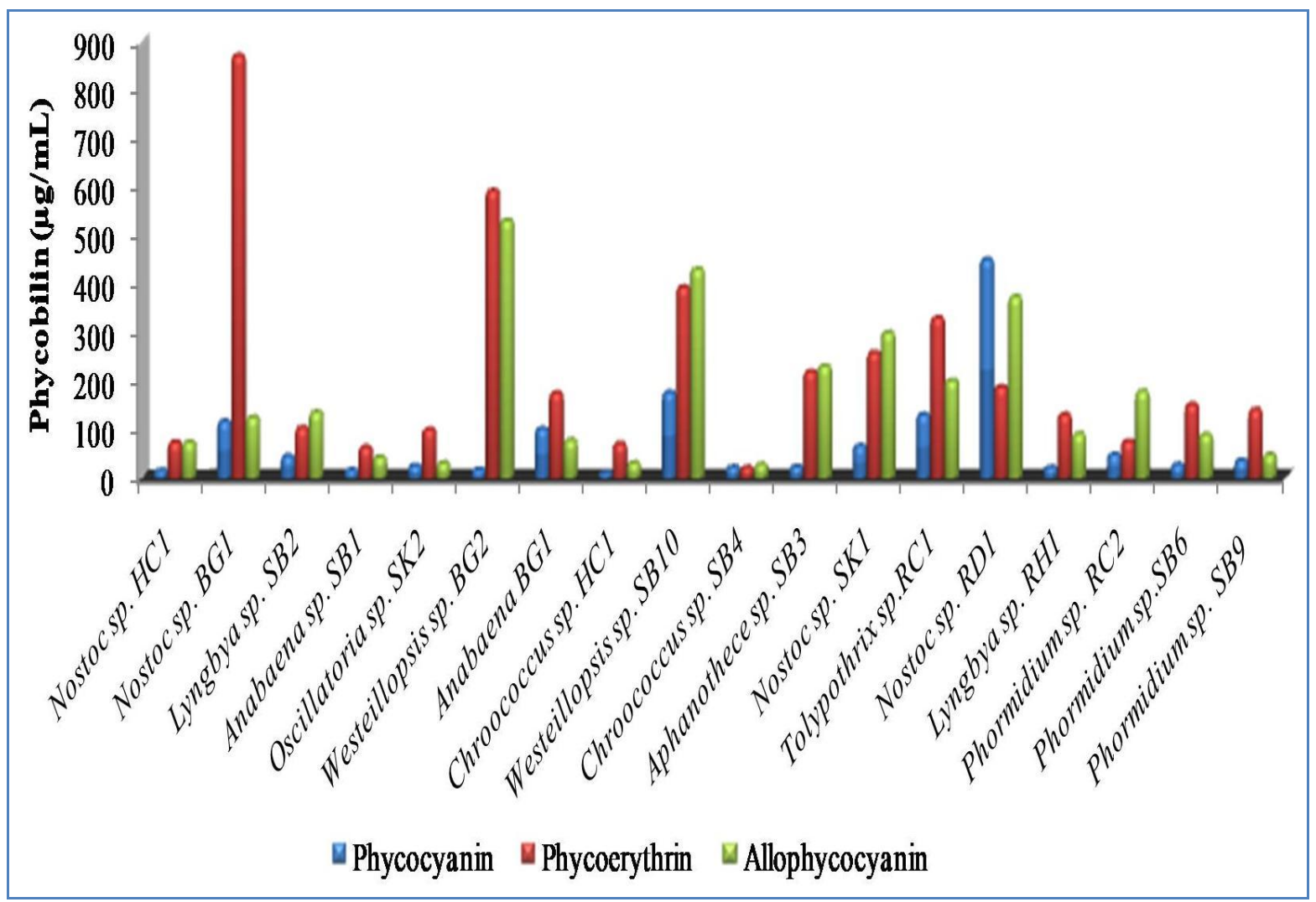


Fig.2 Estimation of chlorophyll from cyanobacteria isolated from different ecological niches of India

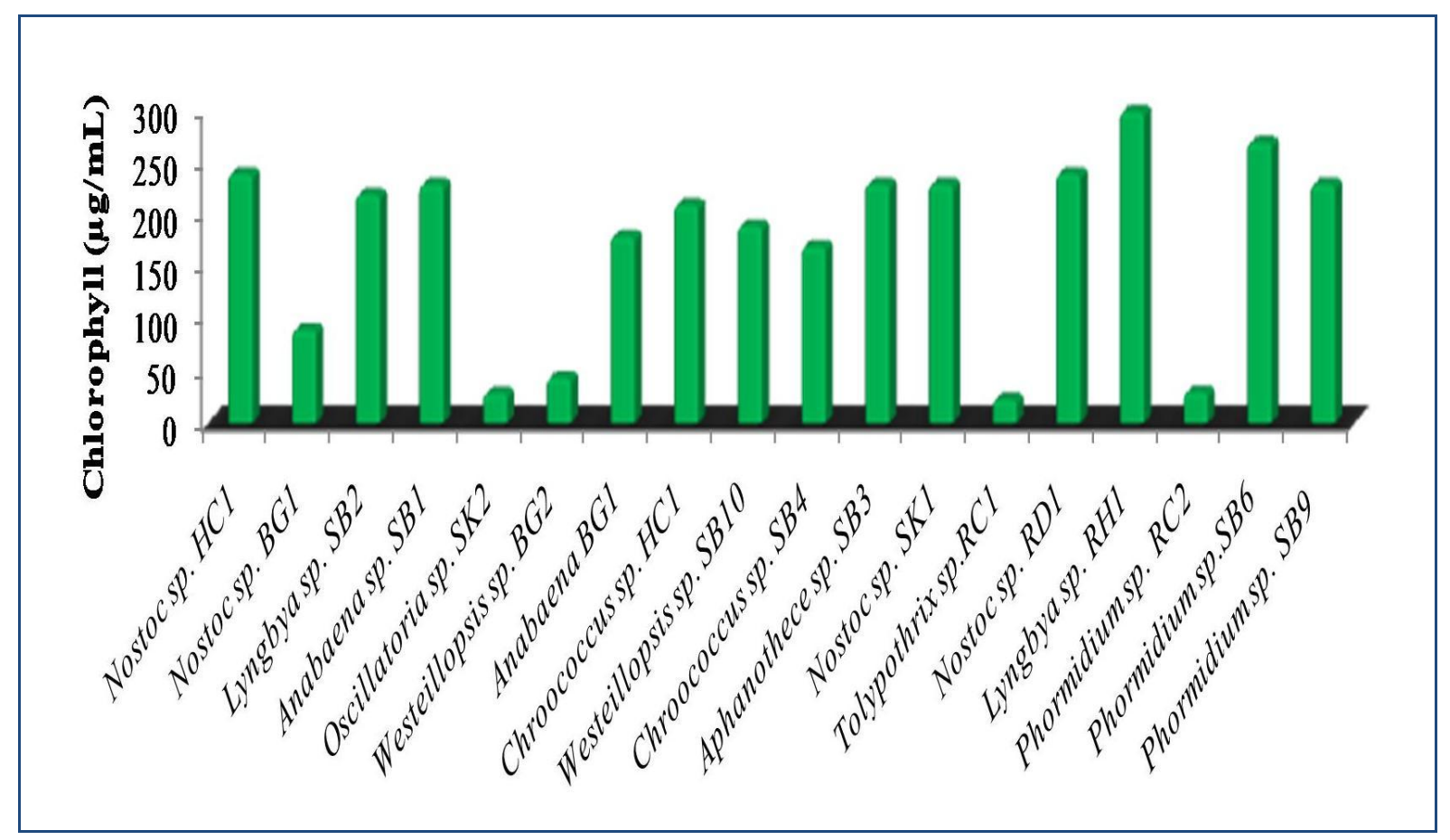

Fig.3 Estimation of total carotenoids from cyanobacteria isolated from different ecological niches of India

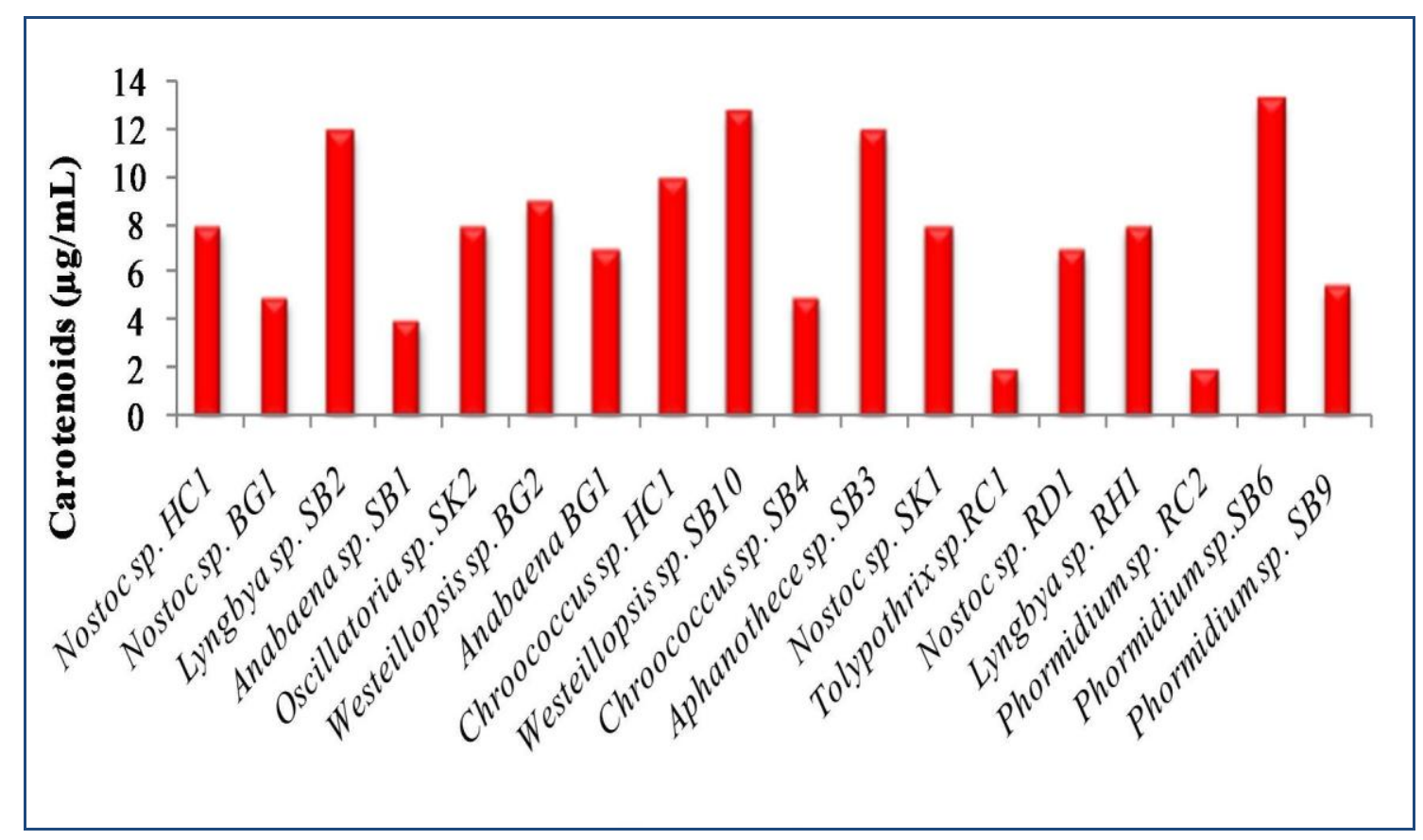


Plate.1 Microphotographs of heterocyst forming cyanobacteria isolated from different ecological niches of India; 1: Anabaena sp. SB1; 2: Anabaena sp. BG1; 3: Nostoc sp. RD1; 4: Nostoc sp. SK1; 5: Nostoc sp. HC2; 6: Nostoc sp. BG1; 7: Westeillopsis sp. BG2; 8: Westeillopsis sp. SB10; Tolypothrix sp. RC1
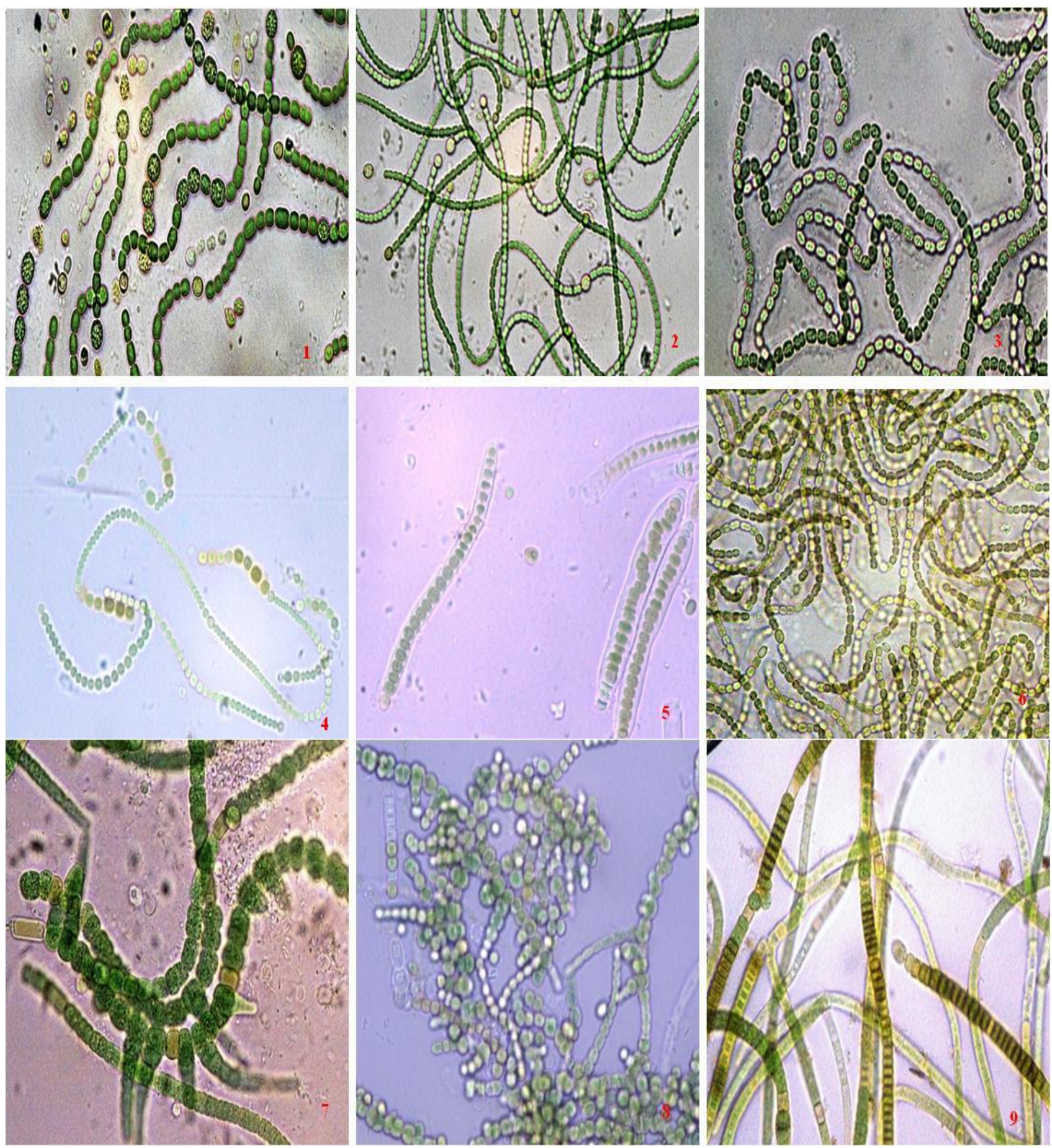
Plate.2 Microphotographs of non-heterocyst forming cyanobacteria isolated from different ecological niches of India; 1: Chroococcus sp. HC1; 2: Chroococcus sp.SB4; 3: Aphanothece sp.; SB3; 4; Phormidium sp. SB9; 5: Phormidium sp.; 6: Phormidium sp. RC2; 7: Lyngbya sp.; 8: Lyngbya sp. SB2; 9: Oscillatoria $\mathrm{sp}$

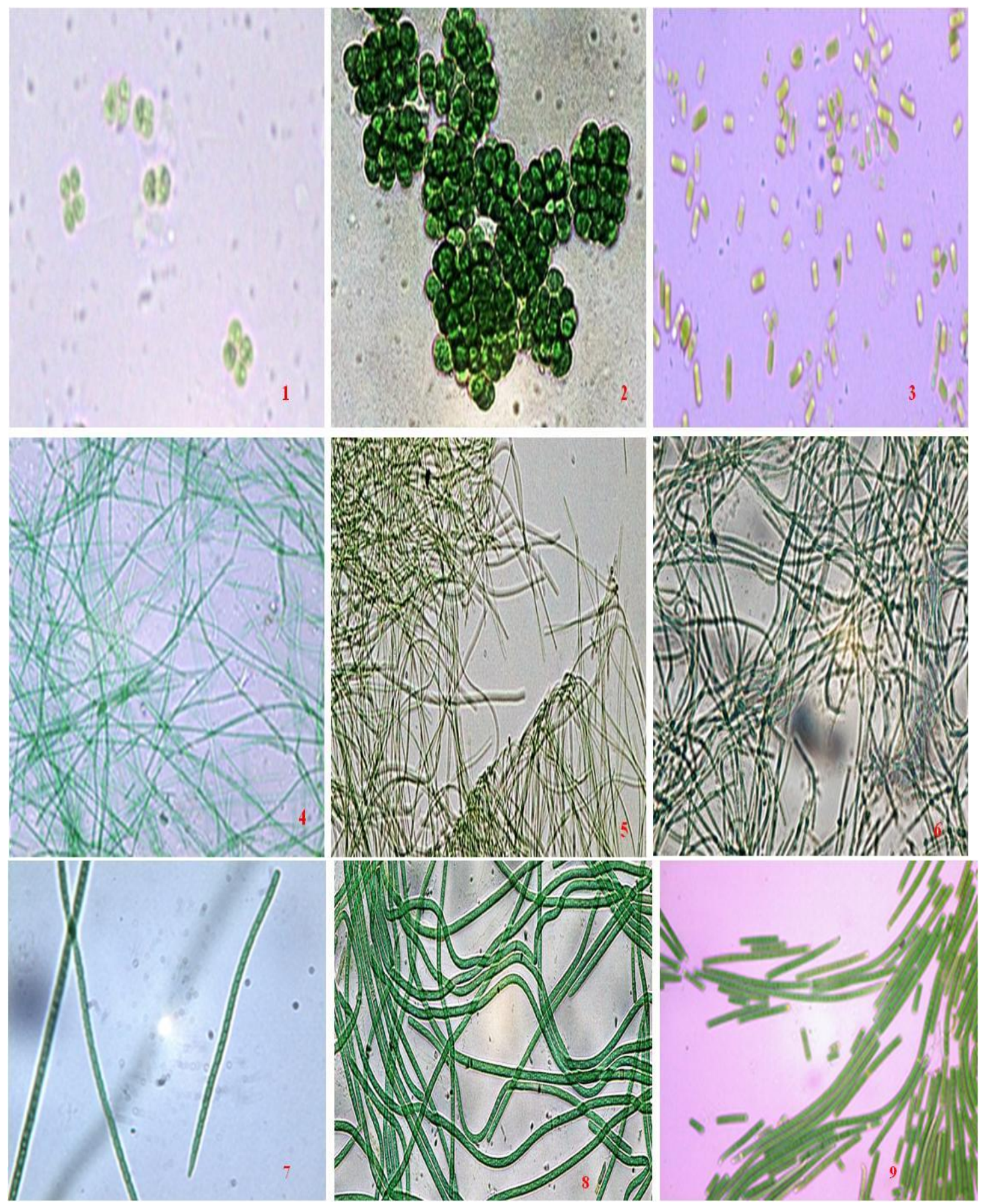


Findings of the study could be useful for further exploitation of these pigment producing strains for commercial applications, however, further investigations are required for optimised conditions for cyaonbacterial strains and improved yield of pigments including phycobilins.

In conclusion, the pycobiliproteins have great potential and large number of applications. There is profound interest in the mass production of these pigments due to their food and pharmaceutical application such as natural colorant in foods, fermented dairy products, beverages etc and biomedical research. The results of the present study indicated that some of the isolates from diverse ecological niches of India have greater potential for phycobiliprotein production. Strains such as Nostoc sp SB7, RD1 and Westeillopsis sp. BG2, are potential candidates for pigment producers since they showed the highest content of phycoerythrin, phycocyanin and allophycocyanin among the studied strains. Still strenuous girth of research is required for high pigment production, process optimization and exploration of new ecological niches for potential pigment producing cyanobacterial strains.

\section{Acknowledgement}

Authors are thankful to Director ICARNBAIM, for providing financial support for the project. Authors also would like to thanks Dr. Sushil K Sharma, Dr. Renu, Dr. Sunil Kumar for providing soil and water samples.

\section{References}

Amchova, P., Kotolova, H. Ruda-Kucerova, J. 2015. Health safety issues of synthetic food colorants. Regul Toxicol Pharmacol. 73: 914-922.

Apt, K.E., Collier, J.L., Grossman, A.R. 1995.
Evolution of the phycobiliproteins. $J$. Mol. Biol. 248 (1) 79-96.

Begum, H., Yusoff, F.M., Banerjee, S., Khatoon, H., Shariff M. 2016. Availability and utilization of pigments from microalgae. Crit Rev Food Sci Nutr. 56: 2209-2222

Bennet, A. and Bogorad, L. 1973. Complementary Chromatic adaptation in a filamentous blue green alga, $J$. Cell Biol., 58: 419-43.

Bhatnagar, A., Bhatnagar M. 2005. Microbial diversity: microbial diversity in desert ecosystems. Curr Sci. 89:91-100.

Chakdar, H., and Pabbi S. 2017. Algal Pigments for Human Health and Cosmeceuticals. Algal Green Chemistry, 171-188.

Chakdar, H., Jadhav, SD., Dhar, DW., and Pabbi Sunil (2012). Potential applications of blue green algae. J. Sci Ind Res. 7(1):13-20.

Chakdar, H., Saha, S., Pabbi, S. 2014. Chromatographic and spectroscopic characterization of phycocyanin and its subunits purified from Anabaena variabilis $\quad$ CCC421 Applied biochemistry and microbiology. 50 (1): 62-68.

Chaneva, G., Furnadzhieva, S., Minkova, K., Lukavsky, J. 2007. Effect of light and temperature on the cyanobacterium Arthronema africanum - a prospective phycobiliprotein producing strain. Appl. Phycol J. 19: 537-544.

Cisneros, M., and Rito-Palomares, M. 2004. A simplified strategy for the release and primary recovery of cphycocyanin produced by Spirulina maxima. Chem Biochem Eng Q. 18(4): 385-390.

CQVB-Centre 1988. Qudbdcois de Vaiorisation de la Biomasse, Etude de MarchO: Survol de MarchO de 34 Produits S l ctionn $\sim$ en vue de la 
Production Eventuelle par Microalgues.

Dasgupta, C.N. 2015. Algae as a source of phycocyanin and other industrially important pigments. In: Algal biorefinery: an integrated approach. Springer, Cham 253-276.

Desikachary, T.V. 1959. Cyanophyta, Indian council of Agricultural Research, New Delhi, India.

Egorova, E.A., Gmoshinskiū, I.V., Zorin, S.N., Mazo, V.K. 2005. Studies of immunomodulation caused by selenium enriched phycocyanin. Voprosypitaniia 75 (2):19-21.

Encarnacao, T., Pais, A., A. Campos, M., G. Burrows, H., D. 2015. Cyanobacteria and microalgae: a renewable source of bioactive compounds and other chemicals. Sci Prog. 98:145-168.

Fresendo, O., Gomez, R., and Serra, J., L. 1991. Carotenoid compostion in the cyanobacterium Phormidium laminosum effect of nitrogen starvation. FEBS Lett. 282:300-304.

Glazer, A.N., and Apell G.S. 1977. A common evolutionary origin for the biliproteins of cyanobacteria rhodophyta and cryptophyta. FEMS Microbiol Lett 1:113-116.

Guiry, M., D. 2012. How many species of algae are there?. J Phycol. 48(5):1057-1063.

Hayashi, T., Hayashi, K., Maeda, M., Kojima I.A. 1996. Natural sulfated polysaccharide, calcium spirulan, isolated from Spirulina platensis, in vitro and ex vivo evaluation of antiherpes simplex virus activities. AIDS Res. Hum. Retriviruses, 12(2):14631471.

Hemlata and Fatma, T. 2009. Screening of cyanobacteria for phycobiliproteins and effect of different environmental stress on its yield. Bulletin if environmental contamination and toxicology. 83(4):509-515.

Hill, C. M., 1988. The photosynthetic apparatus of Marine Macroalgae. Ph.D. Thesis, Department of Biochemistry and Agricultural Biochemistry, University College of Wales.

Horvath, H., Kovacs, AW., Riddick, C., and Presing, M. 2013. Extraction methods for phycocyanin determination in freshwater filamentous cyanobacteria and their application in a shallow lake. Eur j Phycol. 48(3):278-286.

Jensen, A., 1978. Chlorophylls and carotenoides In J. A. Hellbust and I.S. Craig (eds) Handbook of phycological methods: Physiological and biochemical methods, Cambridge University press, 59-70.

Khatoon H, Kok Leong, L., Abdu Rahman, N., Mian, S., Begum, H., Banerjee, S., and Endut, A. 2018. Effects of different ligt sources and media on growth and production of phycobiliprotein from freshwater cyanobacteria. Bioresource Technology. 249:652-658.

Khazi, M.,I. Demirel, Z., and Dalay, M., C. 2018. Evaluation of growth and phycobiliprotein composition of cyanobacteria isolates cultivated in different nitrogen sources. J Appl Phycol. http:/doi.org/10.1007/s10811018-1398-1

Kuddus M., Singh, P., Thomas, G., AlHazimi A. 2013. Recent developments in production and biotechnological applications of C-phycocyanin. Biomed Res Int. 1(9).

Lee NK., Oh HM., Kim HS., Ahn CY. 2017. Higher production of C-phycocyanin by nitrogen-free (diazotrophic) cultivation of Nostoc sp. NK and simplified extraction by dark-cold shock. Bioresour Technol 227:164170 
Lee SH., Lee, JE., Kim, Y., Lee SY. 2016. The production of high purity phycocyanin by Spirulina platensis using light-emitting diodes based two-stage cultivation. Appl Biochem Biotechnol 178:382-395

Linden, H., Sandmann, G., Chamovitz, D., Hirschberg, J., and Böger, P. 1990 Biochemical characterization of Synechococcus mutants selected against the bleaching herbicide norflurazon. Pest Biochem Physiol. 36:46-51 (1989).

Mackinney, G., 1941. Absorption of light by chlorophyll solutions. $J$ Biol Chem.140: 315-322.

Manirafasha E, Ndikubwimana T, Zeng X, Lu Y, Jing K. 2016. Phycobiliprotein: potential microalgae derived pharmaceutical and biological reagent. Biochem Eng J.109:282-296

Olie, J., and Potts, M. 1986. Purification and biochemical analysis of the cytoplasmic membrane from the desiccation-tolerant cyanobacterium Notoc commune UTEX584. Appl Environ Microbiol. 52:706-710.

Santiago-Santos, M.C., Nayalo, P.T., Olvera Ramirez, R., Ortega-Lopez, J., Canizares-Villa-nueva R.O. 2004. Extraction and purification of phycocyanin from Calothrix spp. Process Biochem. 39(12): 2047-2052.

Sarada, R., Manoj, G., Pillai, G., and Ravishanka A. 1999. Phycocyanin from Spirulina $s p$ : influence of processing of biomass on phycocyanin yield, analysis of efficacy of extraction methods and stability studies on phycocyanin, Process Biochemistry. 34:795-801.

Sarada, R., Pillai, M.G., Ravishankar, G. 1999. Phycocyanin from Spirulina sp: influence of processing of biomass on phycocyanin yield, analysis of efficacy of extraction methods and stability studies on phycocyanin. Process Biochem. 34: 795-801.

Sekar, S., and Chandramohan, M. 2008. Phyco-biliproteins as a commodity trends in applied research attends and commercialization. J Appl Phycol.20: 113-136.

Sharma, N.K., Rai, A.K., Stal, L.J. 2014. Cyanobacteria: biology, ecology and evolution. In: Oren, A. (Ed.), Cyanobacteria: An Economic Perspective. John Wiley \& Sons, Ltd., pp. 1-20.

Shukla SP and Kashyap AK (2003). An assessment of biopotential of three cyanobacterial isolates from Antartic for carotenoid production. Indian journal of Biochemistry and Biophysics. 40: 362-366

Simeunovic, J., B. Markovic, S., B. Kovac, D., J. Misan, A., C. Mandic, A., I. Svircev, Z., B. 2012. Filamentous cyanobacteria from vojvodina region as source of phycobiliprotein pigments as potential natural colorants. Food and Feed Research. 39 (1):23-31.

Singh N.K., Sonani, R.R., Rastogi, R.P., Madamwar, D. 2015. The phycobilisomes: an early requisite for efficient photosynthesis in cyanobacteria. EXCLI J 14: 268.

Sobiechowska-Sasim, M., Ston-Egiert, J., and Kosakowska, A. 2014. Quantitative analysis of extracted phycobilin pigments in cyanobacteria - an assessment of spectrophotometric and spectrofluorometric methods. J Appl Phycol. 26(5): 2065-2074.

Sonani, R., Singh, N.K., Kumar, J., Thakar, D., Madamwar, D. 2014. Concurrent purification and antioxidant activity of phycobiliproteins from Lyngbya sp. A09DM, an antioxidant and anti-aging potential of phycoerythrin in Caenorhabditis elegans. Process. Biochem. 49:1757-1766. 
Soni, B., Beena, K., Ujjval, T., Datta M. 2006. Extraction, purification and characterization of phycocyanin from Oscillatoria quadripunctulata-isolated from the rocky shores of Bet-Dwarka, Gujarat, India. Process Biochemistry, 41 (9): 2017-2023.

Stanier, R.Y., Kunisawa, R., Mandel, M., Cohen-Bazire G. 1971. Purification and properties of unicellular bluegreen algae: order Chroococcales.
Bacteriol. Rev. 35: 171-205. Tiwari, O.N., Indrama, T., Singh, K.O., Singh, O.A., Oinam, G. et al., 2015. Enumeration, pigment analysis and nitrogenase activity of cyanobacteria isolated from unexplored rice fields of Manipur, India falling under IndoBurma biodiversity hotspots. Int. J. Curr. Microbiol. App. Sci. 4 (6): 666680.

\section{How to cite this article:}

Samadhan Yuvraj Bagul, Sneha Tripathi, Hillol Chakdar, N. Karthikeyan, K. Pandiyan, Arjun Singh and M. Kumar. 2018. Exploration and Characterization of Cyanobacteria from Different Ecological Niches of India for Phycobilins Production. Int.J.Curr.Microbiol.App.Sci. 7(12): 2822-2834. doi: https://doi.org/10.20546/ijcmas.2018.712.321 